\title{
ANALISIS PEMAHAMAN KONSEP BERDASARKAN GAYA BELAJAR PADA MODEL SCRAMBLE BERBASIS STEAM
}

T Frisca Ninda Safilda ${ }^{1}$, Bambang Sri Anggoro ${ }^{2}$, Rizki Wahyu Yunian Putra ${ }^{3}$, Ahmad Sodiq ${ }^{4}$, Nurhasanah Leni ${ }^{5}$

Universitas Islam Negeri Raden Intan Lampung 1,2,3,4,5

Email: nindasafilda@gmail.com¹, bambangsriangoro@radenintan.ac.id², riskiwahyuyp@radenintan.ac.id³, ahmadsodiq@radenintan.ac.id4 nurhasanahleni@radenintan.ac.id ${ }^{5}$

\begin{abstract}
Abstrak. Tujuan dalam penelitian ini untuk mengetahui; (1) adanya perbedaan antara model pembelajaran Scramble berbasis STEAM (Science, Technology, Engineering, Art, Mathematics) dan pembelajaran model ceramah terhadap kemampuan pemahaman konsep matematis. (2) adanya perbedaan kategori gaya belajar auditorial, visual dan kinestetik peserta didik terhadap pemahaman konsep matematis. (3) adanya interaksi antara faktor model pembelajaran dengan gaya belajar terhadap kemampuan pemahaman konsep peserta didik. Berdasarkan hasil nilai ulangan harian menunjukkan bahwa kemampuan pemahaman konsep matematis peserta didik di SMP Negeri 24 Krui masih rendah, terlihat dalam proses peserta didik menyelesaikan masalah, faktor yang menyebabkan hal ini terjadi adalah banyaknya siswa kurang kesadaran dalam hal memperhatikan dan memahami pelajaran atau bisa dikatakan malas belajar serta metode pembelajaran yang kurang mendukung. Penelitian ini bertujuan untuk mengetahui adakah perbedaan model pembelajaran scramble berbasis STEAM dan pembelajaran model ceramah terhadap kemampuan. pemahaman konsep matematis ditinjau dari gaya belajar.Jenis penelitian ini menggunakan Quasi Experiment Design. Sampel pada penelitian ini adalah kelas eksperimen dan kelas kontrol. Kelas eksperimen diberikan perlakuan model pembelajaran scramble berbasis STEAM, sedangkan kelas kontrol diberikan perlakuan model konvesional dengan model ceramah. Penelitian ini menggunakan teknik analisis data uji Anova dua jalan. Berdasarkan hasil analisis diperoleh kesimpulan bahwa penggunaan model pembelajaran scramble berbasis STEAM (Science, Technology, Egineering, Art, Mathematics) dapat mempengaruhi kemampuan pemahaman konsep peserta didik dan tipe gaya belajar yang dimiliki peserta didik juga dapat mempengaruhi kemampuan pemahaman konsep perta didik.
\end{abstract}

\section{Kata Kunci: Model Scrambel, STEAM, Gaya Belajar}

\begin{abstract}
The purpose of this research is to find out; (1) there is a difference between the STEAM-based Scramble learning model (Science, Technology, Engineering, Art, Mathematics) and the lecture model learning on the ability to understand mathematical concepts. (2) there are differences in the categories of auditory, visual and kinesthetic learning styles of students towards understanding mathematical concepts. (3) there is an interaction between learning model factors and learning styles on the ability to understand students' concepts. This type of research uses Quasi Experiment Design. The sample in this study was the experimental class and the control class. The experimental class was given treatment with the STEAM-based scramble learning model, while the control class was given the conventional model treatment with the lecture model. This study uses a two-way Anova test data analysis technique. Based on the results of the analysis, it can be concluded that the use of STEAM-based scramble learning models (Science, Technology, Engineering, Art, Mathematics) can affect students' conceptual understanding abilities and the type of learning styles possessed by students can also affect students' conceptual understanding abilities.
\end{abstract}

\section{Keywords: $\quad$ Scrambel Model, STEAM, Learning Style}

\section{A. Pendahuluan}

Pendidikan merupakan suatu kebutuhan pokok yang sangat penting bagi kehidupan manusia. Proses pendidikan yang sangat mendasar dimulai dari rumah, yang kemudian dilanjutkan pembelajaran disekolah. Proses pembelajaran disekolah meliputi segala aktivitas serta kegiatan belajar mengajar. Pendidikan memegang peranan untuk mendukung dan 
menyeimbangkan kemajuan dari ilmu pengetahuan dan teknologi, sehingga dengan pendidikan seseorang dapat terlepas dari kebodohan, yang menghasilkan lulusan yang memiliki kualitas dan moral yang tinggi (Anggoro, 2016; Rizki, 2017). Manusia diberikan akal dan pikiran untuk dapat dikembangkan melalui pendidikan, hal ini yang membedakan manusia dengan makhluk lainnya (Anwar, 2014). Pendidikan juga menjadi faktor utama dalam pembentukan pribadi manusia, (Saraswati, Dibia, \& Sudiana, 2013) dan tanpa adanya pendidikan manusia tidak akan tumbuh dengan kualitas yang baik. (Maharani, Nanang, \& Rany, 2018) dan kualitas pendidik menjadi penentu potensi yang nantinya akan dimiliki peserta didik (Aini dkk, 2019). Peserta didik masing-masing memiliki potensi terpendam yang perlu diasah oleh dirinya sendiri serta perantara seorang pendidik. Guru atau pendidik merupakan komponen penting yang sangat berpengaruh dalam peningkatan mutu pendidikan di suatu instansi, baik di sekolah maupun universitas (Badawi, 2015).

Proses pendidikan yang sangat mendasar dimulai dari rumah, yang kemudian dilanjutkan pembelajaran disekolah. Proses pembelajaran di sekolah meliputi segala aktivitas serta kegiatan belajar mengajar. Pelajaran yang wajib dan selalu ada dari jenjang sekolah dasar hingga jenjang perguruan tinggi adalah pelajaran matematika. Pembelajaran matematika secara keseluruhan menekankan pada penemuan pola atau sifat umum dari variabel, angka, dan lain-lain (Anggoro, 2021). Dalam perkembangannya banyak konsep matematika yang diperlukan untuk membantu menyelesaikan masalah dalam kehidupan sehari-hari yang dihadapi, seperti halnya untuk membantu manusia dalam memahami dan menguasai permasalahan sosial, ekonomi, teknologi dan alam. (Syazali, 2015). Matematika memiliki keterkaitan antar konsep dan ide yang abstrak dan terdiri berdasarkan susunan dan penalaran deduktif (Sarniah, Chairul \& Rizki, 2019).

Mengingat betapa pentingnya pelajaran matematika dalam kehidupan, menjadikan peserta didik lebih giat untuk memahami pelajaran tersebut, dan disayangkan memori para peserta didik tentang pelajaran matematika merupakan pelajaran yang sangat sulit. Salah satu kesulitan yang dihadapi yaitu memahami konsep matematika itu sendiri (Kurniawan \& Gustian: 2019). Pemahaman konsep sangat penting dalam pembelajaran dan menjadi dasar untuk berpikir dan belajar untuk memecahkan masalah (Priyambodo, 2016; Sudirman, 2013). Kesalahan dalam Pemahaman konsep matematis yaitu kesalahan karena kecerobohan atau kurang cermat, kesalahan mentransformasikan informasi, kesalahan keterampilan proses, dan kesalahan memahami soal sehingga berdampak pada pemahaman konsep peserta didik (Tama, Achi \& Siska, 2018). Pemahaman konsep juga menjadi modal awal yang harus dikuasai peserta didik (Triana, Ilyas, \& Fahrul, 2019).

Kesulitan peserta didik dalam menguasai pemahaman konsep peneliti temukan ketika melalukan pra penelitian di salah satu Sekolah Menengah Pertama (SMP) kecamatan Krui kabupaten Pesisir Barat.

Tabel 1. Tes Pemahaman Konsep Peserta didik.

\begin{tabular}{lccr}
\hline \multirow{2}{*}{ Kelas } & \multicolumn{2}{c}{ Nilai Matematika Peserta Didik } & Jumlah \\
\cline { 2 - 3 } & $\boldsymbol{X}<75$ & $\boldsymbol{X} \geq \mathbf{7 5}$ & 30 \\
\hline VIII A & 21 & 9 & 31 \\
VIII B & 27 & 4 & 30 \\
VIII C & 23 & 7 & 91 \\
Jumlah & 71 & 20 & \\
\hline
\end{tabular}

Berdasarkan Tabel 1 Data tersebut menunjukkan bahwa terdapat keseluruhan peserta didik sebanyak 91, dimana 71 peserta didik mendapatkan hasil yang rendah, dan 20 peserta didik mampu mendapatkan hasil yang baik sehingga nilai diatas 75 . Hasil tersebut menujukkan bahwa kemampuan pemahaman konsep peserta didik masih rendah. Menurut Suderiyanti yang merupakan guru matematika di sekolahan tersebut mengatakan bahwa faktor yang 
menyebabkan hal ini terjadi adalah banyaknya siswa kurang kesadaran dalam hal memperhatikan dan memahami pelajaran.

Salah satu faktor lain yang mungkin mempengaruhi rendahnya pemahaman konsep peserta didik yaitu model pembelajaran yang kurang inovasi (Yuziman, wawancara $13 \mathrm{Juli}$ 2020). Kondisi tersebut memberikan hasil yang sangat tidak memuaskan sehingga harus diperbaiki. Pemilihan model pembelajaran yang tepat akan berdampak positif dalam perkembangan peserta didik dengan adanya inovasi pembelajaran yang lebih progresif. Model pembelajaran Scramble menurut peneliti adalah inovasi yang bisa digunakan untuk meningkatkan pemahaman konsep. Hal tersebut selaras dengan penelitian yang pernah dilakukan oleh Helma \& Mariati (2020) dengan kesimpulan bahwa penerapan model pembelajaran Scramble dapat meningkatkan pemahaman konsep matematis siswa kelas VII SMP Negeri 5 Batang Gansal. Model pembelajaran Scramble merupakan model pembelajaran yang mengharuskan siswa untuk menggabungkan otak kanan dan otak kiri.dimana dalam pembelajarannya menggunakan media kartu yang disajikan berdasarkan nomor kartu pada kartu dan dimainkan secara berkelompok oleh peserta didik (Shoimin, 2014; Alamsyah \& Andi, 2016). Proses pembeljaran menggunakan model pembelajaran Scramble juga membentuk peserta didik menjadi pribadi yang kreatif. Pribadi kreatif merupakan individu yang mampu mengaktivkan potensi kreativitasnya (Anggoro, 2016). Kemudian untuk menunjang model scramble dalam pembelajaran peneliti menggunakan pendekatan STEAM (Science, Technology, Engineering, Art, Mathematics).

STEAM merupakan sains dan teknologi yang diinterpretasikan melalui teknik dan seni, dan kesemua disiplin tersebut berbasis elemen matematika. Secara komprehensif sebagai pola pemecahan masalah. Dengan kata lain, peserta didik dituntut untuk mampu menganalisa dan berfikir kritis dalam mengolah data dan menyelesaikan suatu masalah dikehidupan sehari-hari (Yakman, 2012). Salah satu yang perlu diperhatikan oleh pendidik adalah, mengetahui kemampuan, minat, keterbatasan serta gaya belajarnya. Mengenali gaya belajar dari seseorang bukan hal yang mudah atau sulit, dengan adanya gaya belajar mampu mencerminkan kemampuan dan pribadi seeorang tersebut. Gaya belajar merupakan salah satu cara seorang dalam memahami, mengolah informasi maupun materi pembelajaran (Karim, 2014). GayaBbelajar pada dasarnya terdiri dari tiga tipe yaitu gaya belajar visual, gaya belajar audiotory, gaya belajar kinestetik, namun ada beberapa peserta didik yang memiliki gaya belajar gabungan (Huda, 2014). Dengan mengetahui tipe gaya belajar yang dimiliki peserta didik, pendidik dapat menentukan strategi atau model pembelajaran yang akan diterapkan dalam pembelajaran (Yusuf \& Mutmainnah, 2016)

Berdasarkan pemaparan di atas tentang pentingnya model pembelajaran yang tepat dan mengetahui tipe gaya belajar yang dimiliki peserta didik dalam meningkatkan pemahaman konsep matemtais, maka peneliti memiliki tujuan penelitian yaitu untuk mengetahui; (1) adanya perbedaan antara model pembelajaran Scramble berbasis STEAM (Science, Technology, Engineering, Art, Mathematics) dan pembelajaran model ceramah terhadap kemampuan pemahaman konsep matematis. (2) adanya perbedaan kategori gaya belajar auditorial, visual dan kinestetik peserta didik terhadap pemahaman konsep matematis. (3) adanya interaksi antara faktor model pembelajaran dengan gaya belajar terhadap kemampuan pemahaman konsep peserta didik.

\section{B. Metode Penelitian}

Penelitian ini merupakan jenis penelitian quasi experiment dimana subjek individu yang akan menjadi subjek kelompok dengan tujuan tertentu. Quasy experiment peneliti gunakan dikarenakan tidak memungkinkan jika bisa mengontrol semua variabel yang relevan kecuali beberapa variabel saja. Sampel dalam penelitian ini menggunakan dua kelompok yaitu kelompok ekperimen dan kontrol. Kelompok eksperimen adalah kelompok yang mendapatkan 
perlakuan model pembelajaran scramble berbasis STEAM (Science, Technology, Engineering, Art, Mathematics) sedangkan untuk kelompok kontrol mendapatkan perlakuan model konvesional dengan metode ceramah.

Tes dan angket menjadi instrumen dalam penelitian ini, dimana tes yang diberikan berupa soal uraian yang menjadi pengukur kemampuan pemahaman konsep peserta didik dan angket yang diberikan berupa pernyataan untuk mengetahui tipe gaya belajar yang dimiliki peserta didik. Variabel penelitian dalam penelitian ini terdiri dari variabel bebas dan variabel terikat. Variabel bebasnya yaitu model pembelajaran scramble berbasis STEAM $X_{1}$ dan gaya belajar $\left(X_{2}\right)$, sedangkan variabel terikatnya yaitu pemahaman konsep (Y). Desain penelitian yang digunakan sebagai berikut:

Tabel 2.Desain Penelitian

\begin{tabular}{lcccc}
\hline \multirow{2}{*}{ Model pembelajaran $\left(\mathrm{A}_{\mathrm{i}}\right)$} & \multicolumn{3}{c}{ Gaya Belajar $\left(\mathrm{B}_{\mathrm{j}}\right)$} \\
\cline { 3 - 4 } & & Tipe 1 $\left(\mathrm{B}_{1}\right)$ & Tipe 2( $\left(\mathrm{B}_{2}\right)$ & Tipe 3 $\left(\mathrm{B}_{3}\right)$ \\
\hline Model pembelajaran & Scramble berbasis & $\mathrm{A}_{1} \mathrm{~B}_{1}$ & $\mathrm{~A}_{1} \mathrm{~B}_{2}$ & $\mathrm{~A}_{1} \mathrm{~B}_{3}$ \\
STEAM $\left(\mathrm{A}_{1}\right)$ & $\mathrm{A}_{2} \mathrm{~B}_{1}$ & $\mathrm{~A}_{2} \mathrm{~B}_{2}$ & $\mathrm{~A}_{2} \mathrm{~B}_{3}$ \\
\hline
\end{tabular}

Keterangan :

A $\quad:$ Model pembelajaran

B $\quad$ : Gaya Belajar

$\mathrm{A}_{1} \quad$ : Model pembelajaran Scramble berbasis STEAM

$\mathrm{A}_{2} \quad$ : Model pembelajaran ceramah

$\mathrm{B}_{1} \quad$ : Gaya belajar visual

$\mathrm{B}_{2} \quad$ : Gaya belajar audiotorial

$\mathrm{B}_{3} \quad$ : Gaya belajar kinestetik

Adapun sampel dalam penelitian ini sebanyak dua kelas, yaitu kelas eksperimen dan kelas kontrol. Teknik analisis yang peneliti gunakan adalah uji normalitas, uji homogenitas, uji hipotesi anova dua jalan, dan uji komparasi ganda.

\section{Hasil dan Pembahasan}

Berdasarkan penelitian yang telah dilakukan oleh peneliti, data penelitian diperoleh melalui tes kemampuan pemahaman konsep dan angket gaya belajar yang diberikan kepada peserta didik. Data tes tersebut disajikan dan dideskripsi pada tabel berikut:

Tabel 3. Deskripsi Data Tes Kemampuan Pemahaman Konsep

\begin{tabular}{lrrr}
\hline & \multicolumn{2}{c}{ Statistics } & \\
\hline $\mathrm{N}$ & \multicolumn{1}{c}{ Eksperimen } & \multicolumn{2}{c}{ Kontrol } \\
\hline Mean & 20 & 20 \\
\cline { 2 - 4 } Median & Missing & 0 & 0 \\
Mode & 77.30 & 67.70 \\
Std. Deviation & 79.00 & 68.00 \\
Range & $71^{\mathrm{a}}$ & 68 \\
Minimum & 11.314 & 10.519 \\
Maximum & 46 & 46 \\
\hline
\end{tabular}

'Hasil pada Tabel 3 dilakukan dengan menggunakan SPSS 25.0 dan didapatkan nilai ratarata (mean), median, modus (mode), standar deviasi (std. deviation), jangkauan (range), nilai 
tertinggi (maxsimum), dan nilai terendah (minimum). Berdasrkan nilai rata-rata yang diperoleh pada kelas eksperimen dan kelas kontrol menunjukkan bahwa kelas eksperimen lebih unguul dibandingkan kelas kontrol.

Tabel 4. Rangkuman Hasil Angket Gaya Belajar

\begin{tabular}{lccr}
\hline \multirow{2}{*}{ Kelas } & \multicolumn{3}{c}{ Gaya Belajar } \\
\cline { 2 - 4 } & Auditorial & Visual & Kinestetik \\
\hline Eksperimen & 3 & 10 & 7 \\
Kontrol & 7 & 7 & 6 \\
\hline
\end{tabular}

Sebaran angket yang telah diisi oleh peserta didik diperoleh data pada kelas eksperimen yang memiliki gaya belajar kategori auditorial sebanyak 3 orang, kategori visual sebanyak 10 orang, dan kategori kinestetik sebanyak 7 orang. Sedangkan data pada kelas kontrol diperoleh gaya belajar kategori auditorial sebanyak 7 orang, kategori visual sebanyak 7 orang, dan kategori kinestetik sebanyak 6 orang.

Tabel 5. Deskripsi Kemampuan Pemahaman Konsep pada Setiap Gaya Belajar

\begin{tabular}{|c|c|c|c|}
\hline \multirow{19}{*}{ Pemahaman Konsep } & \multicolumn{2}{|l|}{ Gaya Belajar } & \multirow{2}{*}{$\begin{array}{l}\text { Statistic } \\
64.00\end{array}$} \\
\hline & audio & Mean & \\
\hline & & Median & 62.50 \\
\hline & & Std. Deviation & 12.428 \\
\hline & & Minimum & 43 \\
\hline & & Maximum & 86 \\
\hline & & Range & 43 \\
\hline & visual & Mean & 70.35 \\
\hline & & Median & 68.00 \\
\hline & & Std. Deviation & 8.177 \\
\hline & & Minimum & 57 \\
\hline & & Maximum & 86 \\
\hline & & Range & 29 \\
\hline & kinestetik & Mean & 81.85 \\
\hline & & Median & 82.00 \\
\hline & & Std. Deviation & 9.397 \\
\hline & & Minimum & 68 \\
\hline & & Maximum & 100 \\
\hline & & Range & 32 \\
\hline
\end{tabular}

Deskripsi data penelitian yang diperoleh berdasarkan hasil tes kemampuan pemhaman konsep dan angket gaya belajar peserta didik disajikan pada tabel di atas, yang menunjukkan perbedaan hasil kemampuan pemahaman konsep pada setiap gaya belajar yang dimiliki peserta didik.

Berdasarkan deskripsi data tes tersebut di atas, dan untuk mengetahui hipotesis penelitian ini ditolak atau diterima, maka selanjutnya peneliti menganalisis hasil yang telah didapatkan menggunakan uji anova dua jalan atau dua arah. Sebelum menggunakan uji anova dua arah, hasil tersebut harus melalui analisis uji pra-syarat yaitu melalui uji normalitas dan uji homogenitas.

\section{Uji Normalitas}

Uji ini dilakukan dengan menggunkan aplikasi SPSS 25.0 untuk melihat kenormalan data pada tes pemahaman konsep dan gaya belajar peserta didik yang dilihat dari nilai sig pada kolom Kolmogorov Smirnov. Adapun hasil yang diperoleh pada tes pemahaman konsep sebagai berikut: 
Tabel 6. Hasil Uji Normalitas Kelas Eksperimen dan Kontrol

\begin{tabular}{|c|c|c|c|c|c|c|c|}
\hline & \multirow[b]{2}{*}{ Kelas } & \multicolumn{3}{|c|}{ Kolmogorov-Smirnov $^{\mathrm{a}}$} & \multicolumn{3}{|c|}{ Shapiro-Wilk } \\
\hline & & Statistic & df & Sig. & Statistic & $\mathrm{df}$ & Sig. \\
\hline \multirow[t]{2}{*}{ Pemahaman Konsep } & Eksperiemn & .111 & 20 & .200 & .979 & 20 & .914 \\
\hline & Kontrol & .139 & 20 & .200 & .974 & 20 & .838 \\
\hline
\end{tabular}

*. This is a lower bound of the true significance.

a. Lilliefors Significance Correction

Hasil perhitungan SPSS yang disajikan pada Tabel 6 diperoleh nilai sig kelas eksperimen pada Kolmogorov Smirnov sebesar 0,200 dan kelas kontrol sebesar 0,200. Nilai tersebut lebih besar dari $\alpha=0,05$ sehingga dapat disimpulkan bahwa sampel (kelas eksperimen dan kontrol) merupakan sebaran yang normal.

Tabel 7. Hasil Uji Normalitas Gaya Belajar

Tests of Normality

Pemahaman Konsep

\begin{tabular}{lrrrrrr}
\multirow{2}{*}{$\begin{array}{l}\text { Gaya } \\
\text { Belajar }\end{array}$} & \multicolumn{2}{c}{ Kolmogorov-Smirnov $^{\mathrm{a}}$} & \multicolumn{3}{c}{ Shapiro-Wilk } \\
\cline { 2 - 7 } & Statistic & df & Sig. & Statistic & df & Sig. \\
\hline auditorial & .113 & 10 & $.200^{*}$ & .980 & 10 & .965 \\
visual & .174 & 17 & .179 & .953 & 17 & .499 \\
kinestetik & .161 & 13 & $.200^{*}$ & .933 & 13 & .370 \\
\hline
\end{tabular}

*. This is a lower bound of the true significance.

a. Lilliefors Significance Correction

Hasil perhitungan SPSS yang disajikan pada Tabel 7 diperoleh nilai sig kategori auditorial pada Kolmogorov Smirnov sebesar 0,200. Nilai sig pada kategori visual sebesar 0,179 dan nilai sig pada kategori kinestetik sebesar 0,200. Nilai sig pada masing-masing kategori gaya belajar tersebut lebih besar dari $\alpha=0,05$ sehingga dapat disimpulkan bahwa sampel merupakan sebaran yang normal.

\section{Uji Homogenitas}

Uji homogenitas dihitung menggunakan aplikasi SPSS 25.0 dengan Test Of Homogeneity Of Variance pada taraf signifikansi sebesar 5\%. Adapun hasil yang diperoleh pada uji homogenitas sebagai berikut:

\section{Tabel 8. Uji Homogenitas Soal}

\begin{tabular}{|llrrrr}
\cline { 2 - 5 } \multicolumn{1}{c}{} & \multicolumn{1}{c}{ Levene } & & & \\
Statistic & df1 & df2 & Sig. \\
\hline Pemahaman Konsep & Based on Mean & .538 & 1 & 38 & .468 \\
& Based on Median & .425 & 1 & 38 & .518 \\
& $\begin{array}{l}\text { Based on Median and with } \\
\text { adjusted df }\end{array}$ & .425 & 1 & 37.912 & .518 \\
& Based on trimmed mean & .558 & 1 & 38 & .460 \\
\hline
\end{tabular}

Hasil perhitungan SPSS pada variansi data kelas eksperimen dan kelas kontrol diperoleh sig pada based on mean yaitu sebesar 0,468. Hal ini menunjukkan bahwa nilai tersebut lebih besar dari $\alpha=0,05$ maka dapat ditarik kesimpulan bahwa kedua variansi berdistribusi homogen.

\section{Uji Hipotesis}

Setelah melalui uji prasyarat dengan perolehan bahwa sampel berasal dari populasi yang normal dan homogen, maka selanjutnya peneliti melakukan uji anova dua jalan. Hasil analisis tersebut dapat dilihat pada tabel berikut: 
Tabel 9. Hasil Analisis Anova Dua Jalan

Tests of Between-Subjects Effects

\begin{tabular}{lrrrrr}
\hline & \multicolumn{1}{c}{ Type III } & & & \\
Sum of & \multicolumn{2}{c}{ Mean } & \\
Squares & \multicolumn{1}{c}{ df } & \multicolumn{1}{c}{ Square } & \multicolumn{1}{c}{ F } & Sig. \\
\hline Corrected Model & $2593.829^{a}$ & 5 & 518.766 & 6.162 & .000 \\
Intercept & 181752.134 & 1 & 181752.134 & 2159.050 & .000 \\
x1 & 531.051 & 1 & 531.051 & 6.308 & .017 \\
x2 & 1656.443 & 2 & 828.221 & 9.839 & .000 \\
x1 ${ }^{*}$ x2 & 20.935 & 2 & 10.468 & .124 & .883 \\
Error & 2862.171 & 34 & 84.182 & & \\
Total & 215706.000 & 40 & & & \\
Corrected Total & 5456.000 & 39 & & & \\
\hline
\end{tabular}

Berdasarkan hasil yang diperoleh dari uji anova dua jalan maka hipotesisi penelitian ini dapat disimpulkan bahwa:

1) $H_{0 A}$ ditolak, karena nilai sig yang diperoleh pada $x 1$ (kelas eksperimen dan kontrol) sebesar 0,017. Nilai yang dihasilkan menunjukkan bahwa sig < 0,05 sehingga dapat diartikan bahwa terdapat perbedaan anatar peserta didik yang diberikan model pembelajaran scramble berbasis STEAM (Science, Technology, Engineering, Art, Mathematics) dengan peserta didik yang diberikan pembelajaran model ceramah terhadap kemampuan pemahaman konsep.

2) $H_{0 B}$ ditolak, karena nilai sig yang diperoleh pada $\mathrm{x} 2$ (kategori gaya belajar) sebesar 0,00 . Nilai yang dihasilkan menunjukkan bahwa sig $<0,05$ sehingga dapat diartikan bahwa terdapat perbedaan kategori gaya belajar visual, auditorial, dan kinestetik terhadap kemampuan pemahaman konsep.

3) $H_{0 A B}$ diterima, karena niali sig yang diperoleh sebesar 0,883. Nilai yang dihasilkan menunjukkan bahwa sig > 0,05 sehingga dapat disimpulkan bahwa tidak terdapat interaksi antara faktor model dengan gaya belajar terhadap kemampuan pemahaman konsep.

Setelah diperolehnya hasil penelitian selanjutnya penelitia melanjutkan analisis terhadap hipotesis nol yang ditolak yaiatu $H_{0 A}$ dan $H_{0 B}$ dengan tujuan untuk melihat sejauh mana perbedaan yang dihasilkan pada tiap kategori. Analisis uji ini dilakukan dengan menggunakan aplikasi SPSS 25.0 dengan metode Scheffe. Adapun rataan marginal dalam analisis ini terangkum sebagai berikut:

Tabel 10. Rangkuman Rataan Marginal

\begin{tabular}{lcccr}
\hline \multirow{2}{*}{ Model Pembelajaran } & \multicolumn{3}{c}{ Gaya Belajar } & \multirow{2}{*}{ Rataan Marginal } \\
\cline { 2 - 4 } & Auditorial & Visual & Kinestetik & 75,957 \\
\hline Scramble & 68,000 & 74,300 & 85,571 & \\
Konvesional & 62,286 & 64,714 & 77,500 & \\
Rataan Marginal & 65,143 & 69,507 & 81,536 & \\
\hline
\end{tabular}

Berdasarkan pada Tabel 10, selanjutnya peneliti melakukan uji komparasi ganda antar kolam yaitu pada gaya belajar peserta didik (auditorial, visual, dan kinestetik). Dengan hasil analisis sebagai berikut: 
Tabel 11. Hasil Uji Komparasi Ganda antar Kolom Multiple Comparisons

\begin{tabular}{llrrrrr}
\hline & & \multicolumn{3}{c}{ Mean } & Std. & \multicolumn{2}{c}{ 95\% Confidence Interval } \\
\cline { 5 - 7 } (I) Gaya Belajar & (J) Gaya Belajar & Difference (I-J) & Error & Sig. & Lower Bound & Upper Bound \\
\hline auditorial & visual & -6.35 & 3.657 & .235 & -15.71 & 3.01 \\
\multirow{3}{*}{ Visual } & kinestetik & $-17.85^{*}$ & 3.859 & .000 & -27.72 & -7.97 \\
\multirow{3}{*}{ Kinestetik } & auditorial & 6.35 & 3.657 & .235 & -3.01 & 15.71 \\
& kinestetik & $-11.49^{*}$ & 3.380 & .007 & -20.15 & -2.84 \\
& auditorial & $17.85^{*}$ & 3.859 & .000 & 7.97 & 27.72 \\
& visual & $11.49^{*}$ & 3.380 & .007 & 2.84 & 20.15 \\
\hline
\end{tabular}

Hasil perhitungan yang disajikan pada Tabel 4.14 menunjukkan bahwa:

1. Hasil perhitungan antara auditorial dan visual diperoleh nilai sig sebesar 0,235. Nilai yang dihasilkan lebih besar dari $0,05(\mathrm{sig}>0,05)$ yang berarti $H_{0}$ diterima sehingga dapat disimpulkan bahwa tidak terdapat perbedaan anatara gaya belajar dengan kategori auditorial dan gaya belajar dengan ketegori visual. Kesimpulan tersbut dapat dilihat juga pada Tabel 4.13 dimana rataan marginal kategori auditorial sebesar 65,143 dan rataan marginal kategori visual sebesar 69,507. Rataan kedua kategori tersebut menunjukkan hasil yang tidak jauh berbeda terhadap kemampuan pemahaman konsep peserta didik.

2. Hasil perhitungan antara auditorial dan kinestetik diperoleh nilai sig sebesar 0,000. Nilai yang dihasilkan lebih kecil dari $0,05($ sig $<0,05)$ yang berarti $H_{0}$ ditolak sehingga dapat disimpulkan bahwa terdapat perbedaan antara gaya belajar dengan kategori auditorial dan gaya belajar dengan kategori kinestetik. Kemudian untuk melihat seberapa besar perbedaanya dan untuk mengetahui manakah kategori yang lebih baik yang dapat mempengaruhi pemahaman konsep dapat dilihat pada Tabel 4.13 dengan hasil rataan marginal pada kategori auditorial sebesar 65,143 dan rataan marginal pada kategori kinestetik sebesar 81,536. Berdasarkan nilai rataan marginal tersebut dapat disimpulkan bahwa peserta didik yang memiliki gaya belajar kategori kinestetik lebih baik dibandingkan dengan peserta didik yang memiliki gaya belajar kategori auditorial terhadap kemampuan pemahaman konsep.

Hasil perhitungan antara visual dan kinestetik diperoleh nilai sig sebesar 0,007. Nilai yang dihasilkan lebih kecil dari $0,05($ sig $<0,05)$ yang berarti $H_{0}$ ditolak sehingga dapat disimpulkan bahwa terdapat perbedaan antara gaya belajar dengan kategori visual dan gaya belajar dengan kategori kinestetik. Kemudian untuk melihat seberapa besar perbedaanya dan untuk mengetahui manakah kategori yang lebih baik yang dapat mempengaruhi pemahaman konsep dapat dilihat pada Tabel 4.13 dengan hasil rataan marginal pada kategori visual sebesar 69,507 dan rataan marginal pada kategori kinestetik sebesar 81,536. Berdasarkan nilai rataan marginal tersebut dapat disimpulkan bahwa peserta didik yang memiliki gaya belajar kategori kinestetik lebih baik dibandingkan dengan peserta didik yang memiliki gaya belajar kategori visual terhadap kemampuan pemahaman konsep.

\section{Kesimpulan}

Berdasarkan hasil analisis diperoleh kesimpulan bahwa penggunaan model pembelajaran scramble berbasis STEAM (Science, Technology, Egineering, Art, Mathematics) dapat mempengaruhi kemampuan pemahaman konsep peserta didik dan tipe gaya belajar yang dimiliki peserta didik juga dapat mempengaruhi kemampuan pemahaman konsep perta didik.

Saran dalam penelitian ini yaitu guru harus mempersiapkan diri dalam mengajar, karena performa guru sangat berpengaruh juga dalam mengembangkan kompetensi peserta didik sehingga tujuan pemeblajaran dapat tercapai. 


\section{DAFTAR PUSTAKA}

Aini, Nur Rohmatul, Syafrimen, Netriwati, Pahrudin A, Rahayu T, and Puspasari V. (2019). "Problem Based Learning for Critical Thinking Skills in Mathematics." Journal of Physics: Conference Series, 1155012026.

Alamsyah, Sai, and Andi Budimanjaya. (2016). 95 Strategi Mengajar Multiple Intellegences: Mengajar Sesuai Kerja Otak Dan Gaya Belajar Siswa. Jakarta: Prenadamedia Group.

Anggoro, Bambang Sri. (2021). Mathematical-Analytical Thinking skills: The Impacts and Interactions of Open-ended Learning Method \& Self-Awareness (Its Application on Bilingual Test Instruments), Al-Jabar: Jurnal Pendidikan Matematika 12 (1): 89-107. https://doi.org/10.24042/ajpm.v12i1.8516

(2016). Analisis Persepsi Siswa SMP Terhadap Pembelajaran Matematika Ditinjau Dari Perbedaan Gender Dan Disposisi Berfikir Kreatif Matematis. Al-Jabar:Jurnal Pendidikan Matematika 7: 153.

(2015). Pengembangan Modul Matematika Dengan Strategi Problem Solving Untuk Mengukur Tingkat Kemampuan Berfikir Kreatif Matematis Siswa. Al-Jabar: Jurnal Pendidikan Matematika.Vol. 6, No. 2, h. 121

Anwar, Chairul. (2014). Hakikat Manusia Dalam Pendidikan, Yogyakarta: Suka-Press

Badawi, Achmad. (2015). Memotivasi Kerja Guru. Jakarta Selatan: Al-Wasat Publishing House.

G. Lee, Yakman. (2012). Exploring the Exemplary STEAM Education in the U. S. As a Practical Education Framework for Kore.” J Korea Assoc. 6. no. 32.

Huda, Miftahul. (2014). Model pembelajaran Dan Pengajaran. Yogyakarta, Pustaka Pelajar.

Karim, Abdul. (2014). Pengaruh Gaya Belajar Dan sikap Siswa Pada Pelajaran Matematika Terhadap Kemampuan Berpikir Kkritis Matematika. FORMATIF: Jurnal Ilmiah Pendidikan MIPA, 4. no. 3.

Kurniawan, Ari Wibowo dan Gustian Erda. (2019). Evaluasi Capaian PISA 2018: Indonesia Perlu Segera Berbenah. Vocational Education policy, White Paper, Vol.1, No.21.

Maharani, Maghfira, Nanang Supriadi, Rany Widyastuti. (2018). Media Pembelajaran Matematika Berbasis Kartun Untuk Menurunkan Kecemasan Peserta didik. Desimal: Jurnal Matematika, 1 (1): 101-106.

Priyambodo, Sudi. (2016). Peningkatan Kemampuan Pemahaman Konsep Matematis Peserta didik Dengan Metode Pembelajaran Personalized System Of Instruction. Jurnal Musharafa, 5 (1): 10-17. 
Putra, R. W. Y. (2017). Analisis Proses Berpikir Kreatif Dalam Memecahkan Masalah Matematika Ditinjau Dari Tipe Kepribadian Guardian Dan Idealis. Nabla Dewantara: Jurnal Pendidikan Matematika, 2 (1).

Saraswati, Nym Lili, I. Kt Dibia, and I. Wyn Sudiana. (2013). Pengaruh Model Pembelajaran Inkuiri Terbimbing Terhadap Hasil Belajar Matematika Peserta didik Kelas III SD di Gugus I Kecamatan Buleleng. MIMBAR PGSD Undiksha , 1 (1).

Sarniah, Siti, Chairul Anwar, and Rizki WahyuYunian Putra, (2019). Pengaruh Model Pembelajaran Auditory Intellectually Repetition Terhadap Kemampuan Pemahaman Konsep Matematis. Journal of Medives: Jounal Of Mathematics Education IKIP Veteran Semarang, 3 (1): 87-96. https://doi.org/10.31331/medivesveteran.v3i1.709

Shoimin, Aris. (2014). 68 Model Pembelajaran Inovatif Dalam Kurukulum 2013. Yogyakarta: Ar-Ruzz Media.

Sudirman. (2013). Interaksi Dan Motivasi Belajar Mengajar. Jakarta: Rajawali Pers.

Syazali, Muhamad. (2015). Pengaruh Model Pembelajaran Creative Problem Solving Berbantuan Media Maole 11 Terhadap KemampuanPemecahan Masalah Matematis. Al-Jabar: Jurnal Pendidikan Matematika, 6(1), 91-98. https://doi.org/10.24042/ajpm.v6i1.58

Tama, Arfani Manda, Achi Rinaldi, and Siska Andriani, (2018). Pemahaman Konsep Peserta Didik Dengan Menggunakan Graded Response Models (GRM). Desimal: Jurnal Matematika, Vol.1, No.1: 91-99, https://doi.org/10.24042/djm.v1i1.2041.

Triana, Nila, Muhammad Ilyas, and Fahrul Basir. (2019). Komparasi Model Pembelajaran Kooperatif Tipe Jigsaw Dan Kooperatif Tipe Teams Assited Individualization (TAI) Terhadap Pemahaman Konsep Matematis Siswa Kelas VII. PROXIMAL, Vol. 2, No. 2.

Yusuf T., M, dan Mutmainnah Amin. (2016). Pengaruh Mind Map Dan Gaya Belajar Terhadap Hasil Belajar Matematika Siswa, Tadris: Jurnal Keguruan Dan Ilmu Tarbiyah, Vol. 1, No. 1. 